\title{
Studies in the liverwort family Metzgeriaceae (Metzgeriales) from southern Africa. 3. The widespread species of Metzgeria
}

\author{
Nonkululo Phephu ${ }^{1}$ and Jacques van Rooy
}

\author{
National Herbarium, South African National Biodiversity Institute, Private Bag X101, Pretoria, 0001, South Africa \\ ${ }^{1}$ Author for correspondence: n.phephu@sanbi.org.za
}

\begin{abstract}
The widespread southern African species, Metzgeria consanguinea, M. furcata and M. leptoneura (Metzgeriaceae) are revised, illustrated and their geographical distributions mapped. Metzgeria furcata is newly reported from Lesotho, and the Free State and Gauteng Provinces of South Africa.
\end{abstract}

\section{Introduction}

Since the revision of African Metzgeria by So (2004), three new records have been reported for the continent, to bring the total number of species to eleven (Ellis et al. 2014). The new records are M. scyphigera Stephani, M. pulvinata Stephani and M. albinea Spruce, all from Rwanda. A taxonomic and historic account of Metzgeriaceae in the Flora of southern Africa (FSA) region, as well as a key to the species, were presented by Phephu and van Rooy (2013). The four southern African species of Metzgeria restricted to Africa and the East African islands (Metzgeria madagassa Stephani, M. nudifrons Stephani, M. quadrifaria Stephani, M. saxbyi Pearson) were treated by Phephu and van Rooy (2014). The aim of this third and last paper in the series is to revise the three remaining, widespread species viz. Metzgeria consanguinea Schiffn., M. furcata (L.) Dumort. and M. leptoneura Spruce.

1. Metzgeria consanguinea Schiffn., Nova Acta Academiae Caesareae Leopoldino-Carolinae Germanicae Naturae Curiosorum 60 (2): 271 (1893); Stephani, Species Hepaticarum 1: 295 (1899); So, New Zealand Journal of Botany 42: 272 (2004). Fig. 1

Type: Java: “in summon apices montis Pangerango”, Karsten s.n. (holotype: FH; isotypes: BM!, FH, G, S, W).

Plants green or yellowish green, occasionally developing light blue patches on gemmae or tapering apex of herbarium (dried) specimens. Thallus (4-)10-20 mm long, 1-1.2 mm wide, flat; branches dichotomous, sometimes arising ventrally on thallus, 1.5-3.5 mm long; wing (12-)18-20(-24) cells wide from midrib to margin; apex tapering, acute or obtuse (dimorphic); margins plane to slightly recurved; costa $0.06-0.08 \mathrm{~mm}$ wide, dorsal cells 2 or 3 , ventral cells 2 or 3 and 10(-15) thick-walled internal medullary cells; lamina cells 25-110 $\mu \mathrm{m}$ long, 15-60 $\mu \mathrm{m}$ wide, regularly hexagonal or polygonal, smooth, walls thin or thick, small trigones present; hairs single, straight or curved, sparse on thallus margins, ventral face of thallus and ventral costa, thallus marginal hairs $0.1-0.2 \mathrm{~mm}$ long, costal hairs $0.08-0.2 \mathrm{~mm}$ long. Gemmae on thallus margins and apices, 0.04-0.2 mm wide, sparse to abundant, ovoid.

Dioicous. Male branches $0.2-0.3 \mathrm{~mm}$ wide, globose, glabrous; female branches (0.4-)0.5-1.3 mm long, 0.2-0.6 mm wide, obovate or obcordate, hairy; calyptra hairy, hairs $0.2-0.5 \mathrm{~mm}$ long; spores not seen. 
Distribution and ecology: Metzgeria consanguinea is mainly pantropical. In southern Africa it occurs in the KwaZulu-Natal and Western Cape Provinces of South Africa as well as Lesotho (Fig. 2). In Africa, it is also known from west Africa and Ethiopia southwards to eastern and southern Africa, as well as the Indian Ocean islands of Comoros, Madagascar and Réunion (So 2004, Wigginton 2009). In southern Africa, Metzgeria consanguinea grows on ledges, in rocky recesses, on rusty metal, and epiphytic on tree bark in cool, shady places, at elevations of 760-1311 m.

Specimens examined: SOUTH AFRICA: KwaZulu-Natal: Bouvie York, 2930AD (see Edwards and Leistner 1971), 1219 m, Sim 1848, May 1920 (PRE); Nels Rust, 2930CD, Sim 1445, Dec 1916, (PRE). Western Cape: Worcester Division, New Year Peak, Slanghoek Mountains, 3319CA, 1311 m, Esterhuysen 24696, Sep 1955 (PRE); Montagu, Swellendam Division, Goedgeloof, Langeberg, 3320CD, S-aspect, Esterhuysen 24529, 3 Sep 1956 (UPS); Table Mountain, Silverstream Ravine, 3318CD, 900 m, Esterhuysen 25101, 11 Dec 1955 (UPS); Ceres Division, Hansieberg, kloof on W slopes, 3319AB, S-aspect, 1200 m, Esterhuysen 25681, 18 Apr 1956 (UPS); Eastern slopes of Table Mountain, Skeleton Gorge, 3318CD, 760 m, Arts RSA104/44, 16 Oct 1996 (BR).

Additional specimens examined: DEMOCRATIC REPUBLIC OF CONGO: Lambinon 72.Z.236 (BM). TRISTAN DA CUNHA: Gough Island: Wace 630f(BM). JAVA: Karsten s.n (BM). KENYA: Agnew 1166 (BM); Fries \& Fries s.n (S). UGANDA: Scott Elliot 180 (BM), Elliot 258 (G). BOLIVIA: Herzog 5048 (G, holotype of M. attenuata Steph., treated as a synonym of M. consanguinea by So (2004).
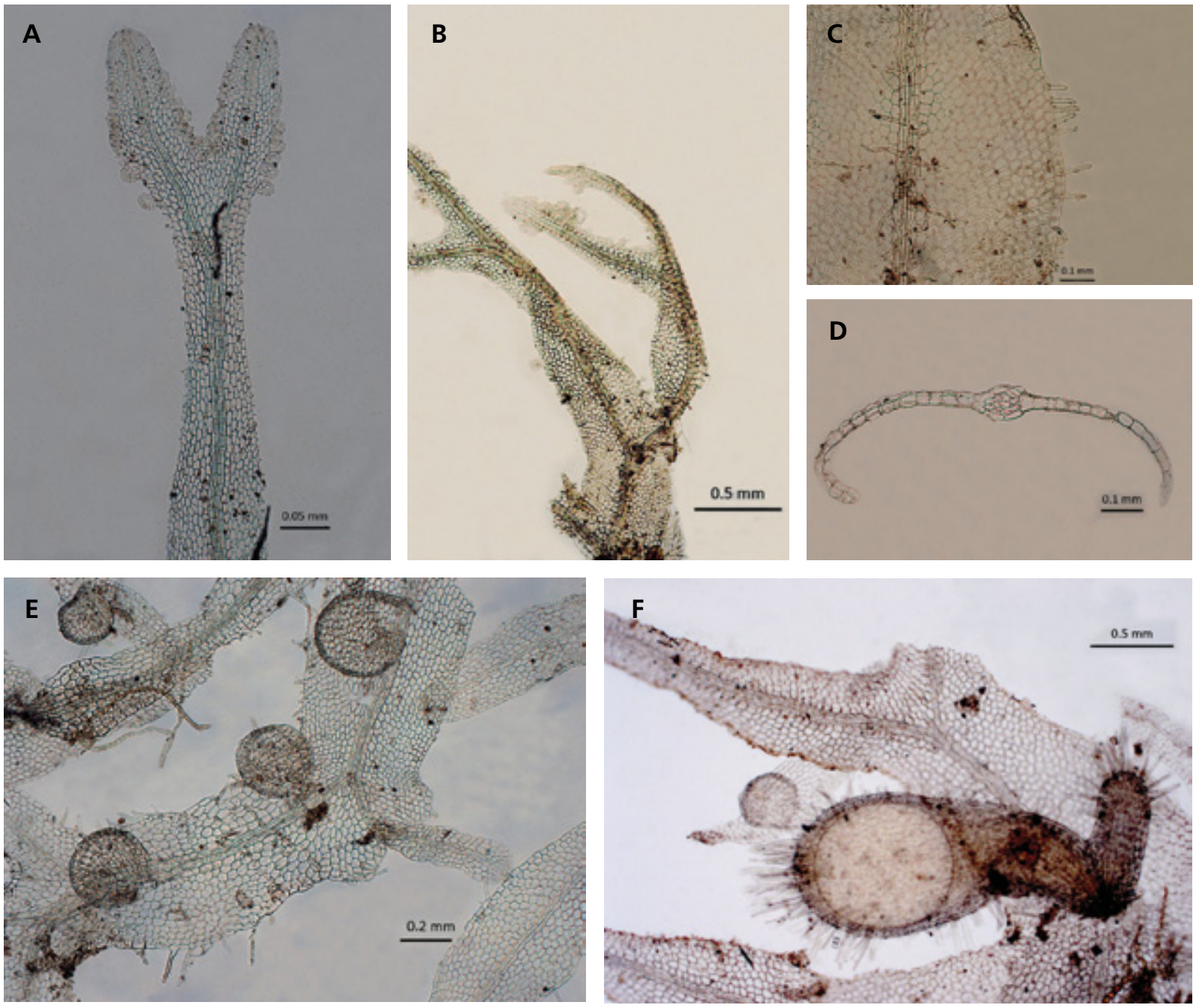

Fig. 1. Metzgeria consanguinea Schiffn.: A, thallus; B, thallus apex showing gemmae; $\mathbf{C}$, laminal cells, marginal and ventral costal hairs; D, cross section of costa; E, ventral surface of thallus with male branchlets. A, B from Esterhuysen 24529 (PRE); C, E from Sim 1848 (PRE); D, F from Esterhuysen 24696 (PRE); F from Sim 1445 (PRE). 
Notes: Metzgeria consanguinea is recognized by its blue-tipped, tapering thallus apices with abundant, concave blue-tinged gemmae, and dorsal and ventral costa of 2 or 3 cells throughout the thallus. The description and illustrations of M. violacea (Ach.) Dumort in Arnell (1963) is based on material collected and determined by T.R. Sim and that we confirmed as M. consanguinea. The occurrence of $M$. consanguinea in the Free State Province, as reported by Perold (2006), based on the BM specimen Cooper 3431 listed by So (2004), could not be confirmed.

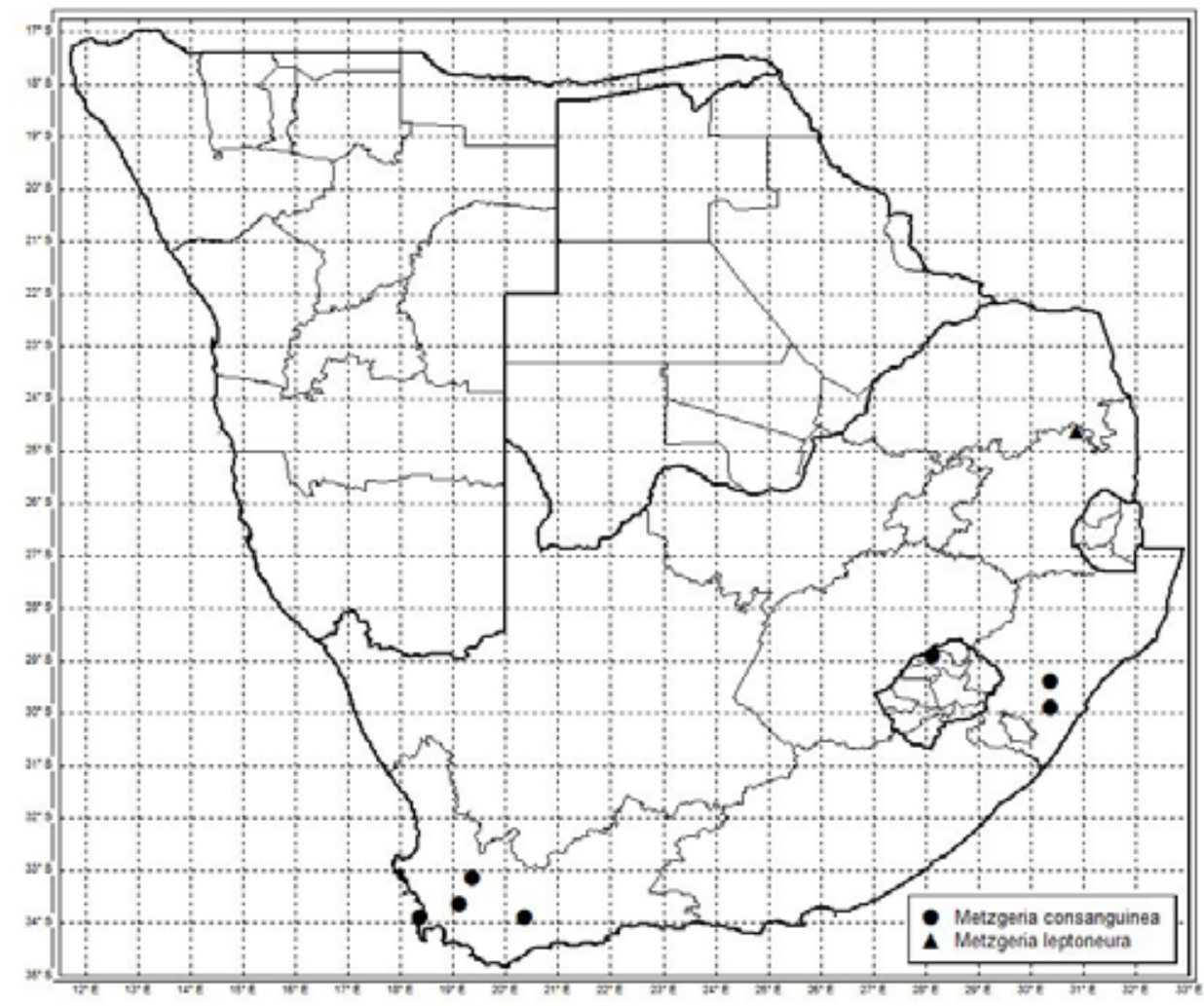

Fig. 2. Distribution of Metzgenia consanguinea (dot) and M. leptoneura (filled triangle) in southern Africa.

2. Metzgeria furcata (L.) Corda, Naturalientausch 12: 654 (1829); So, New Zealand Journal of Botany $42: 276$ (2004).

Jungermannia furcata L., Species Plantarum (ed. 1) 2, 1136 (1753). Fig. 3

Type: (illustration) "Lichenastrum tenuifolium, furcatum, thecis globosis pilosis" in Dillenius, Historia Muscorum t. 74, f. 45 A-C, F and G (lectotype, designated by Grolle and So 2002: 119); Herb. Dillenius fol. 163 , n. 45 (epitype: OXF, designated by Grolle and So 2002: 120; isoepitype: H-SOL!).

Metzgeria capensis S.W.Arnell, Svensk Botanisk Tidskrift 47 (1): 107 (1953).

Type: South Africa: Cape Province, Knysna, Garden of Eden, Arnell 2150 (holotype: not located); Arnell 2118 (paratype: S!).

Metzgeria nicomariei Veltman \& Potgieter, South African Journal of Botany 66: 112 (2000).

Type: South Africa: Mpumalanga, Kangwane, Farm Duurstede, (The Bearded Man), 1280 m, 2531CB, Veltman and Potgieter 12, 7 Dec 1992 (holotype: PRU; isotype: PRE!).

Metzgeria perrotana Stephani, Species Hepaticarum 1: 286 (1899).

Type: South Africa: Montagu Pass, Rehmann 200 (lectotype: G45407!, designated by So 2004; isolectotype: FH). Madagascar, distr. Tamatave, prope Fenerive, Perrot 349, anno 1896 (residual syntypes: FI, G12845!).

Metzgeria tabularis Stephani, Denkschriften der Kaiserlichen Akademie der Wissenschaften / MathematischNaturwissenschaftliche Classe 88: 725 (1913).

Type: South Africa: Tafelberg Bei Kapstadt, Brunnthaler 1909, Mar 1968 (holotype: G3449!; isotype: W). 
Plants green to yellowish green. Thallus $10-30 \mathrm{~mm}$ long, $0.5-1.3 \mathrm{~mm}$ wide, almost of uniform width, usually flat or convex; branches dichotomous, arising from margins or ventrally on thallus; wing (6-)13(-20) cells wide from midrib to margin, dorsal face nude, ventral face sporadically hairy; apex rounded or retuse, reddish-tipped; margins plane to weakly recurved; costa $0.08-0.09 \mathrm{~mm}$ wide, dorsal cells 2 , ventral cells 2 or 3(or 4) and (6-)1014(-18) medullary cells in four rows; laminal cells (16-)30-40(-90) $\mu \mathrm{m}$ long, 30-50 $\mu \mathrm{m}$ wide, hexagonal, smooth to weakly papillose, trigones small; hairs single, rarely geminate, straight or sometimes curved, sparse on thallus margins, ventral face thallus and ventral costa, marginal hairs $(0.04-) 0.1-0.2 \mathrm{~mm}$ long, costal hairs $0.1-0.2 \mathrm{~mm}$ long. Gemmae on thallus margins, $0.3-0.6 \mathrm{~mm}$ wide, discoid, hairy, hairs $0.02-0.05 \mathrm{~mm}$ long.

Dioicous. Male branches $0.3-0.4 \mathrm{~mm}$ wide, globose, nude; female branches $0.5-1 \mathrm{~mm}$ long, $0.4 \mathrm{~mm}$ wide, ovate, triangular-cordate or broadly obovate, hairy; calyptra $0.2-0.5 \mathrm{~mm}$ long, pyriform or clavate, densely hairy, hairs up to $0.2 \mathrm{~mm}$ long, straight; seta (0.8-) 1.0-1.4 mm long, capsule $0.5 \mathrm{~mm}$ long, globose to subglobose, 4-valved; elaters 1-spiral, (8-) 10-12 $\mu \mathrm{m}$ wide; spores $20-27 \mu \mathrm{m}$, round.
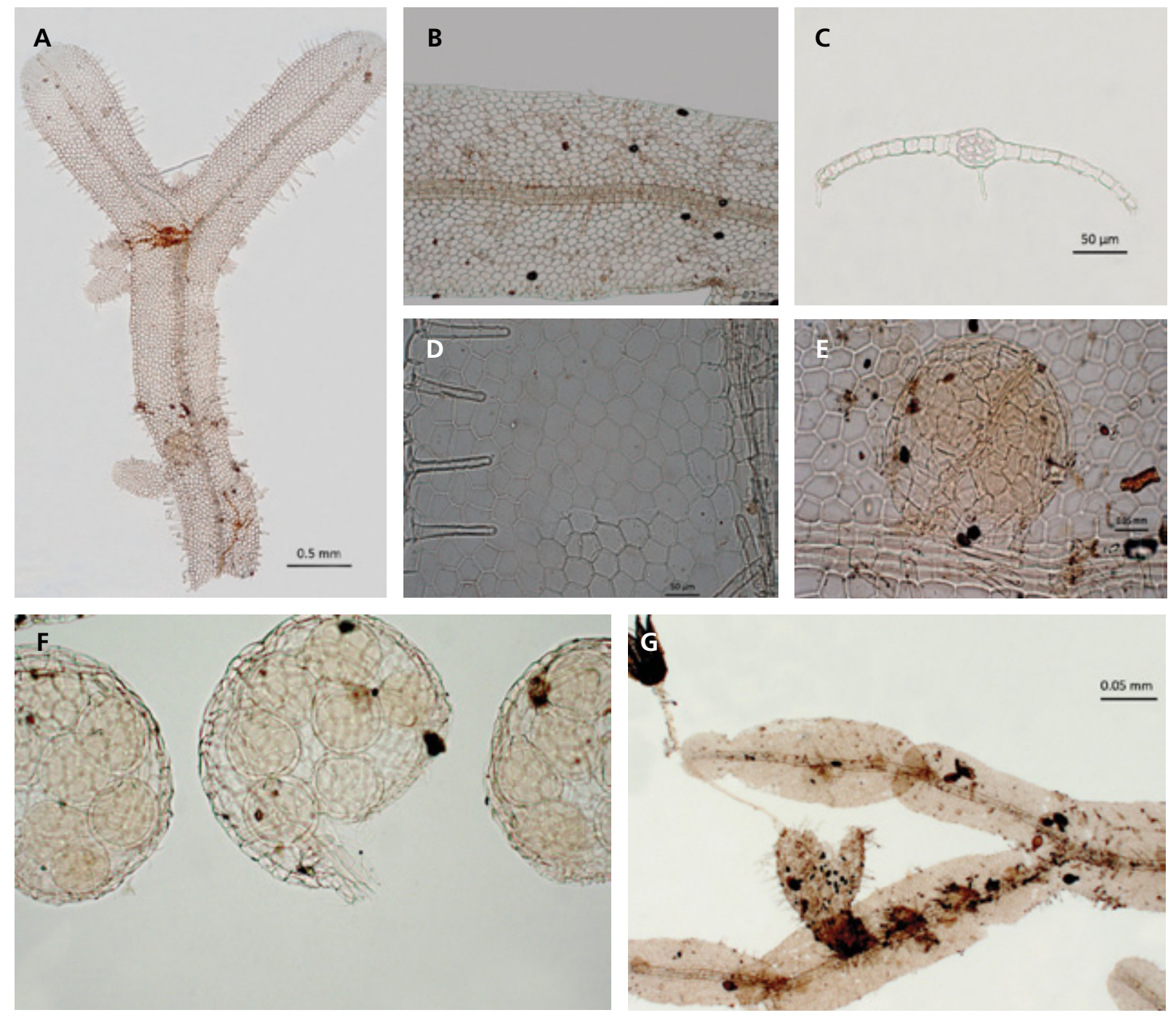

Fig. 3. Metzgeria furcata Stephani: A, thallus, with marginal gemmae; B, G marginal and ventral costal hairs; C, cross section of costa; D, laminal cells; E, antheridium; F, oospores; G, female branch with calyptra and capsule valves. A, E from Sim CH1428 (PRE); C from Wager 2113 (PRE); D from Sim 1520 (PRE); F from Perold \& Koekemoer 4268 (PRE).

Distribution and ecology: Metzgeria furcata is subcosmopolitan and reported from all continents except Antarctica. In southern Africa, it was previously known from Mpumalanga, KwaZulu-Natal, Eastern Cape and the Western Cape Provinces of South Africa (Perold 2006). The species is now also reported from Lesotho, Free State and Gauteng Provinces (Fig. 4). It is also known from tropical to southern Africa and the Indian Ocean islands of Madagascar, Mauritius and Réunion (So 2004, Wigginton 2009). Metzgeria furcata grows in the shade on the bark of trees or shrubs, rocks, walls, soil (sand and humus), or on other bryophytes, on river banks, streams, wooded areas or wet montane. It is found on S-facing aspects, at elevations of 303-1800 m. 
Specimens examined: EASTERN CAPE: Alexandria Forest, Longbush kop, 6 miles inland, 3326CB, Sim CH1862, CH1409, 25 Oct 1920 (PRE); Perie Forest, 3227CB, 1067 m, Leighton 1441, anno 1915 (PRE); King Williams Town, Hogsback, 3227CA, Sim 1436, 12 Oct 1915 (PRE); Grahamstown, 3326BC, Hepburn 4 (PRE); 'Maiu', 914 m, Young 7470 (PRE). GAUTENG: Hartebeeshoek Satellite Tracking Station, \pm 1450 m, 2527 DC, van Rooy 4006, Mar 2001 (PRE). KWAZULU NATAL: Monk's Cove, near campsite, on way to gorge, 2929AB, Perold \& Koekemoer 4268, Dec 1999 (PRE), Ngoya Forest, Zululand, 2831DC, 305 m, Sim CH1428, 1915 (PRE); Nottingham Road, 2930AC, Van der Byl 11, 8 Apr 1917 (PRE); Drakensberg, Cathedral Peak Forest Reserve, Indumeni Forest, Podocarpus forest, 2829CC, 1600-1800 m, van Rooy 1657, Dec 1984 (PRE). MPUMALANGA: Lydenburg, Buffelskloof Nature Reserve, Secret Falls, high forest area, below falls, 2530AD, 1550 m, Glen, 3334, 23 May 2002 (PRE); Belfast, 2530CA, Wager 2113 (PRE). WESTERN CAPE: Knysna, Garden of Eden, 3423AA, Arnell 2118, 30 Nov 1951 (S), Arnell CH4079, CH4083 (PRE); Knysna, Diepwalle Forest Reserve, 3323CC, Arnell 1913, 28 Nov 1951 (S); Table Mountain, above Kirstenbosch Garden, 3318CD, Arnell CH4082, 10 Sept 1951 (PRE); Knysna, Diepwalle Forest Reserve, 3323CC, Arnell CH4081 (PRE); Cape Province, Mac Owen? 177 (PRE); Knysna, 3323CC, Rehm 317, 28 Nov 1951 (PRE); Table Mountain, Newlands Ravine, 610 m, 3318CD, Sim 1520 and CH1500, Jan 1919 (PRE); Cape Town, Table Mountain, Window Gorge Waterfall, 3318CD, 610 m, Sim CH1371, Jan 1919 (PRE); Kloof off Bains Kloof, 3319CA, Primos 1525, Dec 1925 (PRE); Cape Town, upper part of Kirstenbosch, 3318CD, Pillans 3349, 19 Jan 1919 (PRE); Table Mountain, 3318CD, Mitchell 1412, 1918 (PRE).

Additional specimens examined: CAMEROON: Preuss s.n. (BM). MADAGASCAR: Perrot 349 (G). PRINCE EDWARD ISLANDS: Rand B24111 (S). SÃO TOMÉ: Excell 608a (BM); Quintas 1888 (BM, S, G, isotype of M. thomeensis Stephani, regarded as a synonym of M. furcata by So, 2004); Quintas s.n. (G, holotype of M. thomeensis). SIERRA LEONE: Jones 1427, 1473a, 1509 (BM). TANZANIA: Jones 2280, 2281; Pócs 6158/AK, 6372AJ (BM); Pócs T. et D.M 6372 p.p. (BM). USA: Stegazzini 112 (YPM).

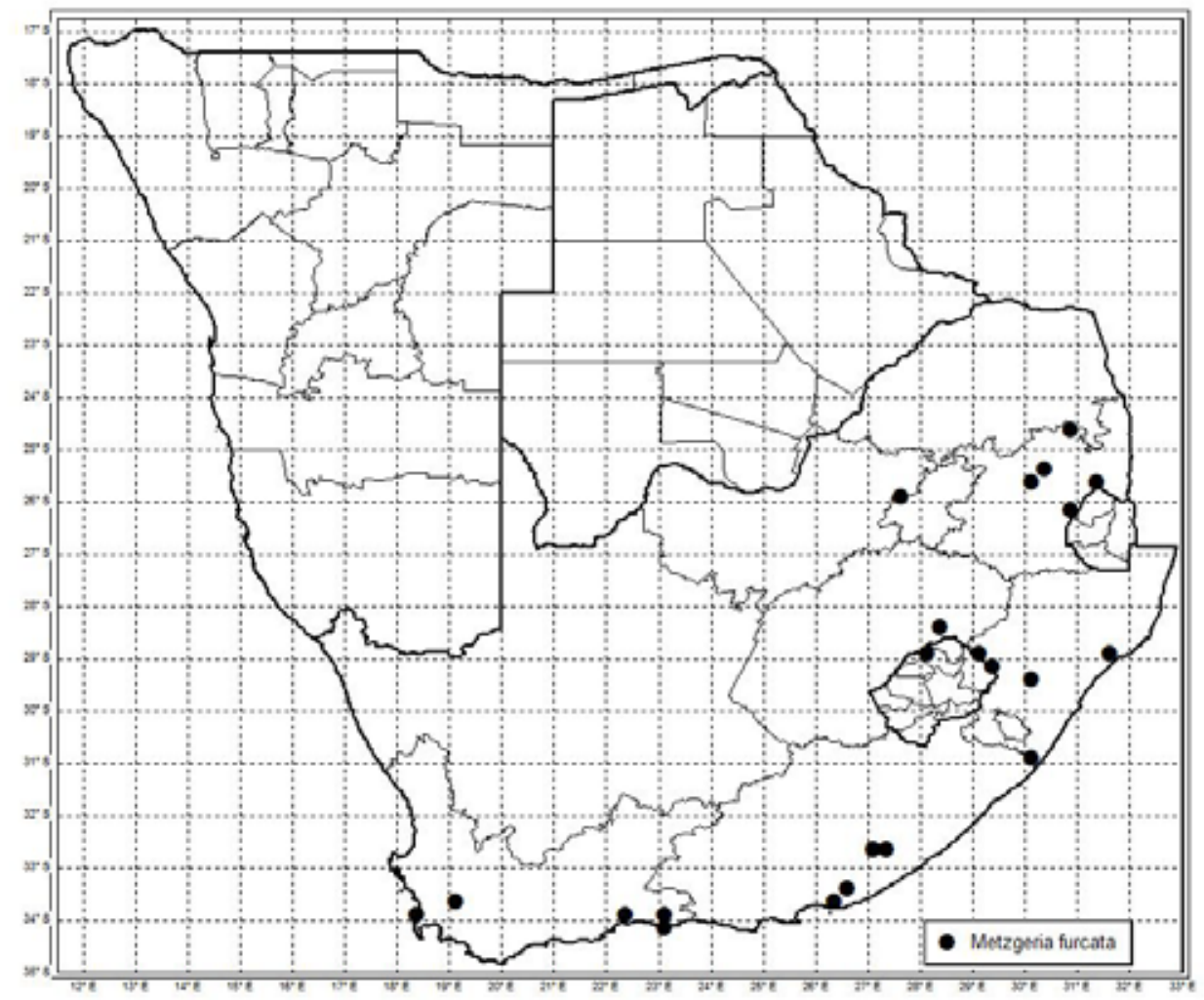

Fig. 4. Distribution of Metzgenia furcata (dot) in southern Africa.

Notes: Arnell (1963) recognized four different species, three of which are now synonyms of $M$. furcata, viz. Metzgeria capensis S.W. Arnell, M. tabularis Stephani, M. perrotana Stephani (So, 2004).

Kuwahara (1983) indicated that he had examined the holotype of M. capensis (voucher: Arnell 2150) in UPS and reduced it to synonymy under M. decipiens (C. Massal.) Schiffn. Costa (2008), in her monograph of neotropical Metzgeria, followed Kuwahara and treated M. decipiens (C. Massal.) Schiffn. as a synonym of the 
pantropical M. ciliata Raddii. We could not locate the holotype in UPS or S and follow So (2004) in treating $M$. capensis as a synonym of $M$. furcata. The relationship between the closely related $M$. furcata and $M$. ciliata needs further investigation.

Veltman and Potgieter (2000) described a new species, M. nicomariei Veltman \& Potgieter, which was later reduced to synonymy under $M$. furcata by So (2004).

Metzgeria furcata is a very variable species and is easily confused with $M$. madagassa. This species is recognized by its non-tapering branches, costa of 2 or 3 dorsal and and 2 or 3 (or 4) ventral cells, marginal hairs usually single, rarely paired (less than $5 \%$ ).

A phylogeographical study by Fuselier et al. (2009) identified three distinct lineages of M. furcata in Europe and North America. However, until southern Hemisphere material are studied, we follow So (2004) in recognising $M$. furcata as a variable species with a subcosmopolitan distribution.

3. Metzgeria leptoneura Spruce, Transactions and Proceedings of the Botanical Society of Edinburgh 15: 555 (1885); So, New Zealand Journal of Botany 42: 278 (2004). Fig. 5

Type: Peru: In monte Campana andinum, Spruce s.n. (holotype: MANCH 19520!; isotypes: F, G17844, W).

Plants light green to yellowish. Thallus (10-)20-60 mm long, 0.5-1.2(-2) mm wide; distinctly convex, may look almost tubular; green to yellowish green; branches irregular or sparingly dichotomous, sometimes arising ventrally on thallus; apex obtuse, furcate; margins strongly recurved; costa c. $0.1 \mathrm{~mm}$ wide, prominent on both faces, 2 dorsal, 2 or 3 ventral and (10-)20-24 medullary cells in 3 or 4 rows; wing strongly incurved, (9-)15-20 cells wide from costa to margin, dorsal face nude; laminal cells 20-65 $\mu \mathrm{m}$ long, 16-60 $\mu \mathrm{m}$ wide, hexagonal or polygonal, trigones lacking or very small; hairs paired, straight to distinctly curved, on thallus margins, ventral face of thallus and ventral costa, c. $0.06-0.3 \mathrm{~mm}$ long. Gemmae occasional, $0.03-0.2 \mathrm{~mm}$ wide, flat, oblong to sub-linear, formed from thallus margins.

Dioicous. Male branches c. $0.2 \times 0.4 \mathrm{~mm}$, globose or subglobose, nude; female branches broadly obovate, rotundovate, $0.2-1 \mathrm{~mm}$ long, $0.1-0.2 \mathrm{~mm}$ wide, hairy; calyptra pyriform, hairy, hairs c. $0.4 \mathrm{~mm}$ long.

Distribution and ecology: In southern Africa, Metzgeria leptoneura is only known from Mariepskop on the Drakensberg escarpment of Mpumalanga Province of South Africa.(Fig. 2). In the rest of Africa and surrounding islands it is known from Bioko, Cameroon, Democratic Republic of Congo, Equatorial Guinea, Guinea, Kenya, Madagascar, Malawi, Mauritius, Niger, Nigeria, Principe, Réunion, Rwanda, São Tomé, Seychelles, Tanzania, Uganda and Zimbabwe (So 2004, Wigginton 2009). Metzgeria leptoneura is a subcosmopolitan species and grows in montane forests, against stream banks, on moist rocks, in shade or direct sunlight at elevations of 1470-1500 m. It sometimes grows mixed with other bryophytes e.g. Polytrichum commune Hedw. and Hookeriopsis utacamundiana (Mont.) Broth.

Specimens examined: MPUMALANGA: Pilgrim's Rest, Mariepskop, near dam, in Klaserie River, 2430DB, Vorster 573 (PRE); Pilgrim's Rest, Mariepskop, along concrete road between forestry station and summit, 2430DB, Vorster 826 (PRE).

Additional specimens examined: BIOKO: Mönkemeyer s.n. (BM). CAMEROON: Dusén 412, 652, 1297; Junguen s.n., Preuss s.n. (BM). DEMOCRATIC REPUBLIC OF CONGO: Loango Coast, Micholitz s.n. (BM). KENYA: Allan s.n. (BM, isotype of M. allanii Stephani, treated as a synonym of M. leptoneura by So, 2004), Allan s.n. (G010249, holotype of M. allanii), Allan s.n. (G101248, paratype of M. allanii). MADAGASCAR: Berthieu s.n. (G12854, lectotype of M. renauldii Stephani, treated as a synonym by So, 2004), Dr Berson 298 (G12853), Borgen s.n. (BM), Sikora s.n. (BM). NIGER: Mőnkemeyer s.n. (BM). PRINCIPE: Quintus s.n. (BM). SÃO TOMÉ: Preuss s.n. (BM), Moller s.n. (BM). PERU: Spruce s.n. (MANCH 19520).

Notes: Metzgeria leptoneura is distinguished by its distinctly convex thallus and abundant, distinctly curved, paired marginal and ventral costal hairs. 

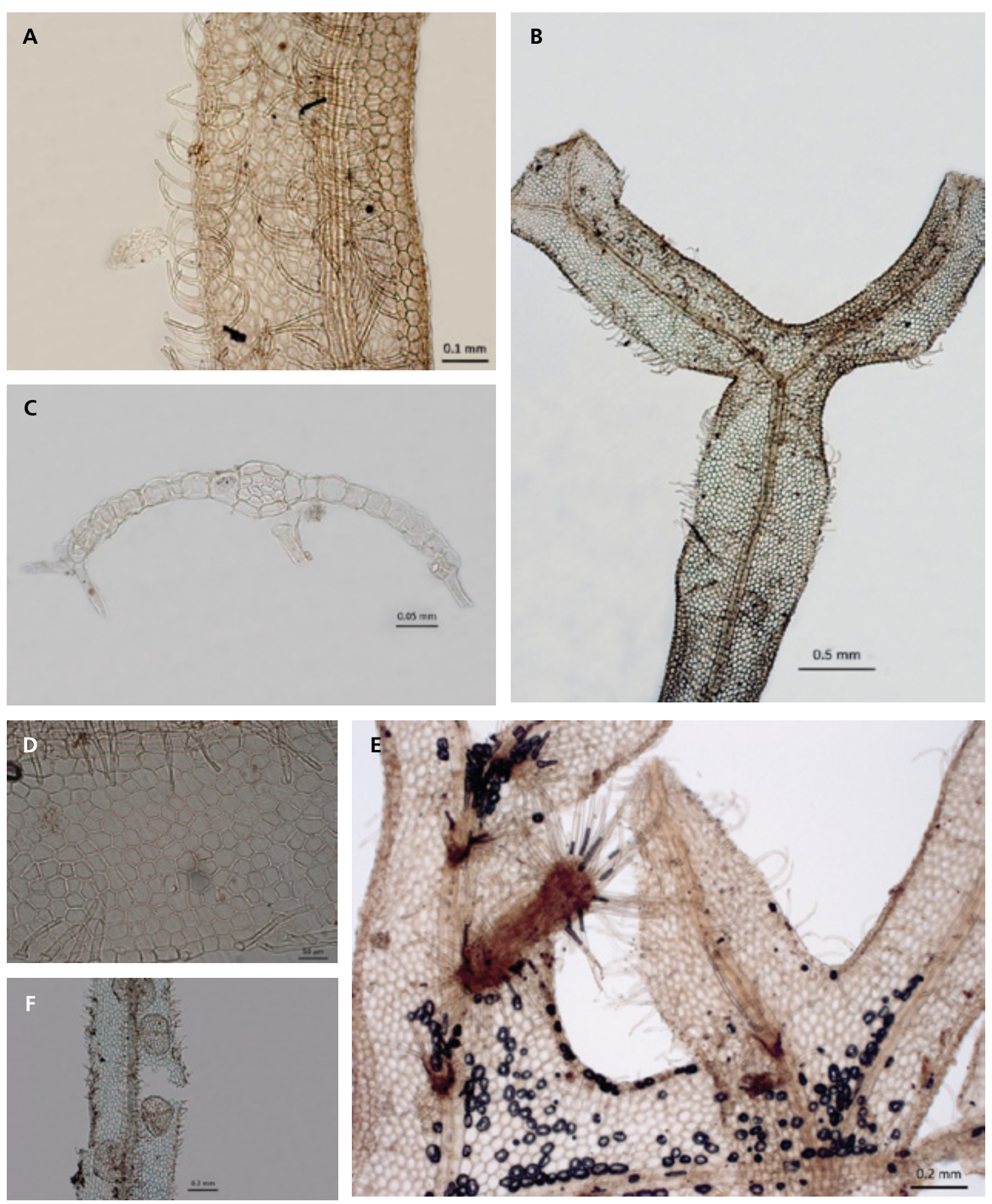

Fig. 5. Metzgeria leptoneura Spruce: A, thallus; B, marginal and ventral coastal hairs; $\mathbf{C}$, cross section of costa; $\mathbf{D}$, laminal cells; E, ventral surface of thallus with male branchlets; F, ventral thallus surface with female branchlets; A, E from Vorster 573 (PRE); C, D, F from Vorster 826 (PRE). 


\section{Acknowledgments}

We would like to thank Mr Alpheus Mothapo (PRE) for coordinating the loans for the revision of southern African Metzgeriaceae, Mr Katleho Mofolo (PRE) for making the image plates, Mr Thabo Masupa (PRE) for making the distribution maps, Dr Denise da Costa (RB) for hosting one of us (Nonkululo Phephu) at her herbarium and allowing us to examine the material, and the following herbaria for allowing us to examine their specimens: BM, BR, G, MANCH, PRE, RB, S, UPS and YPM.

\section{References}

Arnell, S (1963) Hepaticae of South Africa. Swedish Natural Science Research Council, Stockholm

Edwards D, Leistner OA (1971) A degree reference system for citing biological records in southern Africa. Mitteilungen der Botanischen Staatssammlung München 10: 501-509

Ellis LT, Aleffi M, Asthana AK, Srivastava A, Bakalin VA, Batan N, Özdemir T, Bednarek-Ochyra H, Borovichev EA, Brugués M, Cano, MJ, Choi SS, De Beer D, Eckstein J, Erzberger P, Fedosov VE, Ganeva A, Natcheva R, Garcia CA, Sérgio C, Garilleti R, Albertos B, Puche F, Gücel S, Higuchi M, Hugonnot V, Hylander K, Kırmacı M, Aslan G, Koponen T, Lara F, Mazimpaka V, Van Melick H, Müller F, Özenoglu Kiremit, H, Papp B, Szurdoki E, Plášek V, Čihal L, Van der Pluijm A, Poponessi S, Mariotti MG, Reyniers J, Sabovljević MS, Sawicki J, Smith VR, Stebel S, Ştefănuț S, Sun B-Y, Váňa J, Venanzoni $\mathrm{R}$ (2014) New national and regional bryophyte records 40. Journal of Bryology 36 (3): 223-244 http://dx.doi.org/10.1179/1743282014Y.0000000115

Fuselier L, Dadison PG, Clements M, Shaw B, Devos N, Heinrichs J, Hentschel J, Sabovljevic M, Szövéenyi P, Schuette S, Hofbauer W, Shaw AJ (2009) Phylogeographic analyses reveal distinct lineages of the liverworts Metzgeria furcata (L.) Dumort. and Metzgeria conjugata Lindb.(Metzgeriaceae) in Europe and North America. Biological Journal of the Linnean Society 98.4: 745-756

Grolle, R. \& So, M. L. 2002. Typification of three old names of Metzgeria species (Hepaticae): Jungermannia furcata L. 1753, J. linearis Sw. 1788 and J. pubescens Schrank 1792. Cryptogamie Bryologie 23: 119-121

Hodgetts NG, Matcham HW, Duckett JG (1999) Bryophytes collected in Lesotho, the Natal Drakensberg and the Orange Free State, southern Africa. Journal of Bryology 21: 133-155

Kuwahara Y (1983) Metzgeria decipiens (Mass.) Schiffn. (Hepaticae), with a wide geographical distribution. Nova Hedwigia 38: 603-616

Mucina L, Rutherford MC (eds.) (2006) The vegetation of South Africa, Lesotho and Swaziland. Strelitzia 19. South Africa National Biodiversity Institute, Pretoria, South Africa

Perold SM (2006) Hepatophyta. In Germishuizen G, Meyer, NL, Steenkamp Y, Keith M (eds). A checklist of South African plants. Southern African Botanical Diversity Network Report No. 41. SABONET, Pretoria

Phephu N, van Rooy J (2011) Note on the occurrence of Metzgeria saxbyi in southern Africa. Journal of Bryology 33: 85 http://dx.doi.org/10.1179/1743282010Y.0000000013

Phephu N, van Rooy J (2013) Studies in the liverwort family Metzgeriaceae (Metzgeriales) from southern Africa. 1. Metzgeria nudifrons Stephani and a key to the species. Polish Botanical Journal 58 (2): 449-455 http://dx.doi.org/10.2478/pbj-2013-0045

Phephu N, van Rooy J (2014) Studies in the liverwort family Metzgeriaceae (Metzgeriales) from southern Africa. 2. The African species. Telopea 17: 311-318 http://dx.doi.org/10.7751/telopea20147839

So ML (2002) Metzgeria (Hepaticae) in Australasia and the Pacific. New Zealand Journal of Botany 40: 603-627

So ML (2004) Metzgeria (Metzgeriaceae, Marchantiophyta) in Africa. New Zealand Journal of Botany 42: 271-292 http://dx.doi.org/10.1080/0028825X.2004.9512904

van Rooy J, Van Wyk AE (2010) The bryofloristic regions of southern Africa. Journal of Bryology 32: 80-91 http://dx.doi.org/10.1179/037366810X12578498136039

van Rooy J, Van Wyk AE (2011) The bryofloristic elements of southern Africa. Journal of Bryology 33: 17-29 http://dx.doi.org/10.1179/1743282010Y.0000000007

Wigginton MJ (2009) Checklist and distribution of the liverworts and hornworts of sub-Saharan Africa, including the East African Islands. Tropical Bryology Research Report 8: 1-116 